\title{
Influence of Pressure on Al-Si Alloys System
}

Iva Nová, Jiř́i Machuta, Ivan Skalický

Faculty of Mechanical Engineering, Technical University of Liberec, Studentská 2, 46117 Liberec 1, Czech Republic. E-mail: iva.nova@tul.cz, jiri.machuta@tul.cz, ivan.skalicky@constellium.com

The article deals with the calculation of temperature, the maximal solubility of the solid solution and determination of the eutectic temperature of the system Al-Si under the influence of elevated pressure. Monitoring effects of pressure on the equilibrium system Al-Si has an importance for the study of the crystallisation of aluminium alloys under pressure. Alloys based on aluminium and silicon, commonly referred as silumin, are the most important foundry aluminium alloys. First time binary alloys of this type were made by French chemist Sainte-Clair Devil more than 150 years ago. They showed low mechanical properties $(\mathrm{Rm}=98 \div 117 \mathrm{MPa}, \mathrm{A}=1 \div 3 \%)$. That changed in 1921 when the American A. Pacz discovered the effect of sodium on the crystallization of these alloys, that achieved thanks to this a significant increase in mechanical properties $(\mathrm{Rm}=166 \div 225 \mathrm{MPa}, \mathrm{A}=2 \div 8 \%)$. $\operatorname{Recently}$, these alloys are processed by squeeze casting (crystallization under pressure). Casting alloys with high corrosion resistance, low coefficient of linear shrinkage, satisfactory mechanical and casting properties (excellent fluidity, low tendency to shrinkage during moulding), which moreover are good in welding and brazing $[1,2,6,8,15,18$, 19, 20].

Keywords: Al-Si alloy, squeeze casting, pressure, freezing temperature

\section{Acknowledgement}

This publication was written at the Technical University of Liberec as part of the Student Grant Contest "SGS 21122" with the support of the Specific University Research Grant, as provided by the Ministry of Education, Youth and Sports of the Czech Republic in the year 2017.

\section{References}

[1] MURRAY, J. L., MCALISTER, A..J. (1984). The Al-Si (Aluminium-Silicon) System. In: Bulletin of Alloy Phase Diagrams Vol.5, No.1, pp $74-84$.

[2] MII, H., SENNO, M., FUJISHIRO, I. (1976). Solid Solubility of Si an Al Under High Pressure. In: Japan Journal of Applied Physic. Vo. 15, No. 5, May.

[3] FUJISHIRO, I., MII, H., SENOO, M., AKAO, M. (1971). High Pressure Phase Diagram of Al-Si System. Faculty of Engineering, University Nagoya, Japan.

[4] WU, H.C. (1992). Thermodynamic Calculation of Partial Diagram of Al-Si Alloy at High Pressure. In: Journal of materials Science Letters 11, pp. 1-5.

[5] AXON, H., J. PHIL, D. HUME-ROTHERY, W. (1948). The lattice spacing of solid solutions of different elements in aluminium. Proc. Roy Soc. A 193, pp. 1-24.

[6] SOBCZAK, J.J, DRENCHEV, L., ASTHANA, R. (2012). Effect of Pressure on Solidification of Metallic Materials. In: International Journal of Cast Material Research, vol. 25. No1., pp. 1-14.

[7] MATSUMURO, A., SAKAI, K., SENOO, M. (1993). High Pressure Phase Diagram of an Aluminium - Rich AlLi Alloy at a Pressure of. 5.4 GPa. In: Journal of Materials Science .Vol. 28, pp. 6567-6570.

[8] DJURDJEVIČ, M.B., MANASIJEVIČ, S., ODANOVIČ, Z., DOLIČ, N. (2013). Calculation of Liquid Temperature for Aluminium and Magnesium Alloys Applying Method of Equivalency. In: Advances in Material Sciences and Engineering Vol. 2013, article ID 172527, 8 pages.

[9] BATISHEV, A. I. (1977). Crystallization of metals and alloys under of pressure. Metallurgija Moskva (in Russian).

[10] BATISHEV, A. I. (2002). Solidification of Metals and Alloys Under Pressure. Cambridge, Cambridge International Science Publishers.

[11] HALLSTEDT, B., SCHNEIDER, J.M. (2012). A simple approach to pressure dependence, examplified in the AlMg-Si system. Materials Chemistry, RWTH Aachen, Germany.

[12] LIU, X., OIKAWA, K. (2014). Assessment of Temperature and Pressure dependence of Molar Volume and Phase Diagrams of Binary Al-Si Systems. Materials Transactions, Vol. 55, No. 11, pp. 1673-1682. 
[13] SHINYAEV, A.Y., CHERNOV, D.B., KHOKHLOVA, G.I. (1972). Thermodynamic Calculation of phase Equilibria in the Al-Si System at High Pressure. In Russian, TR. Russ. J. Phys. Chem. 46 (11), pp. 1667-1669.

[14] BROSH, E., MAKOV, G., SHNECK, R.Z. (2007). CALHPAD - Computer Coupling of Phase Diagrams and Thermochemistry 31, pp. 173-185.

[15] SHMITZ, J., HALlSTEDT, B., BRILlO, J., EGRY, I., SHICK, M. (2012). Density and thermal expansion of liquid Al-Si alloys. In: Journal of Materials Science. Vol. 47 (8) pp. 3706-3712.

[16] GHOMACHCHI, M.R., VIKHROV, A. (2000). Squeeze casting an overview. In: Journal of materials Processing Technology. Vol. 101., Iss. 1-3, pp. 1-9.

[17] JAYARAMAN, A., KLEMENT, W., KENNEDY, G.C. (1963). Melting and Polymorphism at High Pressures in Some Group IV Elements and III-V Compounds with the Diamond/Zincblende Structure. In: Physical Review. Vol. 130, p. 2277.

[18] LIPINSKI, T. (2015). Influence of Surface Refinement on Microstructure of Al-Si Cast Alloys Processed by Welding Method. In: Manufacturing Technology. Vol. 15, No. 4, pp. 576 - 581. ISSN 1213-2489.

[19] LIPINSKI, T. (2015). Modification of Al-11\% Si Alloy with Cl - Based Modifier. In: Manufacturing Technology, Vol. 15, No. 4, pp.581 - 587. ISSN 1213-2489.

[20] NAPRSTKOVA, N., CERVINKA, R., KUSMIERCZAK, S., CAIS, J. (2015). Modifications AlSi9CuMnNi Alloy by Antimony and Heat Treatment and Their Influence on the Resulting Structure. In: Manufacturing Technology, Vol. 15, No. 4, pp.634 - 638. ISSN 1213-2489. 